\title{
Profile of blinatumomab and its potential in the treatment of relapsed/refractory acute lymphoblastic leukemia
}

This article was published in the following Dove Press journal:

OncoTargets and Therapy

24 June 2015

Number of times this article has been viewed

\author{
Josep-Maria Ribera \\ Albert Ferrer \\ Jordi Ribera \\ Eulàlia Genescà \\ Clinical Hematology Department, \\ ICO-Hospital Germans Trias i Pujol, \\ Josep Carreras Research Institute, \\ Universitat Autònoma de Barcelona, \\ Badalona, Spain
}

\begin{abstract}
The CD19 marker is expressed on the surface of normal and malignant immature or mature B-cells. On the other hand, immunotherapy involving T-cells is a promising modality of treatment for many neoplastic diseases including leukemias and lymphomas. The CD19/CD3-bispecific T-cell-engaging $\left(\right.$ BiTE $\left.^{\circledR}\right)$ monoclonal antibody blinatumomab can transiently engage cytotoxic T-cells to CD19+ target B-cells inducing serial perforin-mediated lysis. In the first clinical trial, blinatumomab showed efficacy in non-Hodgkin's lymphomas, but the most important trials have been conducted in relapsed/refractory (R/R) acute lymphoblastic leukemia (ALL) and in ALL with minimal residual disease. Encouraging reports on the activity of blinatumomab in R/R Philadelphia chromosome-negative B-cell precursor ALL led to its approval by the US Food and Drug Administration on December 3, 2014 after an accelerated review process. This review focuses on the profile of blinatumomab and its activity in R/R ALL.
\end{abstract}

Keywords: acute lymphoblastic leukemia, relapsed/refractory, $\mathrm{BiTE}^{\circledR}$ monoclonal antibodies, blinatumomab

\section{Introduction}

Immunotherapy is a promising modality of treatment for many neoplastic diseases including leukemias and lymphomas. ${ }^{1}$ Among the several strategies used, the engagement of cytotoxic T-cells to the neoplastic cells irrespective of their T-cell receptor specificity has led to highly effective lysis of these cells. Two therapeutic modalities have been demonstrated to be useful for the treatment of B-cell leukemias and lymphomas. The first uses the ectopic expression of a CD19-specific chimeric antigen receptor (CAR) construct in transfected autologous T-cells of patients (CAR T-cells). ${ }^{2-4}$ The second modality includes the bispecific CD19/CD3 T-cell-engaging monoclonal antibody (MoAb), blinatumomab, which can transiently engage any cytotoxic T-cell to CD19+ target B-cells..$^{5-8}$ Both CAR T-cells and blinatumomab have been successfully used in patients with B-cell precursor (BCP) acute lymphoblastic leukemia (ALL), non-Hodgkin's lymphomas, and chronic lymphocytic leukemia.

With regard to $\mathrm{BCP}$ ALL, the CD19 marker has been used as a target for immunotherapy. ${ }^{2}$ Several generations and types of CD19 CAR T-cells have been developed showing a high efficiency in the lysis of CD19-positive blast cells. ${ }^{3,4}$ In turn, blinatumomab has demonstrated promising activity and a favorable safety profile in relapsed/refractory (R/R) ALL and in ALL with minimal residual disease (MRD), and is currently being evaluated in first-line therapy in adults with BCP ALL. ${ }^{5-8}$ 
Here, we review the pharmacologic profile, the clinical results, and the safety and tolerability of blinatumomab for treating R/R BCP ALL.

\section{Pharmacologic profile of blinatumomab Mechanism of action of blinatumomab}

A bispecific T-cell-engaging $\left(\mathrm{BiTE}^{\circledR}\right)$ antibody is made up of the variable antigen-binding domains of two antibodies connected by a non-immunogenic peptide acting as a linker. ${ }^{9}$ This construct allows to engage the T-cells to the target neoplastic cell, subsequently activating the T-cells and causing the perforin-mediated death of the malignant cell. ${ }^{10}$ Blinatumomab (derived from "B lineage-specific antitumor mouse monoclonal antibody") is the most clinically advanced $\mathrm{BiTE}^{\circledR}$ antibody, and includes an anti-CD3 arm to engage CD3-expressing T-cells and an anti-CD19 arm to bind to lymphoblasts expressing the CD19 marker. More than $90 \%$ of cases of BCP ALL express CD19 in more than 20\% of malignant cells, the intensity of expression being sufficient to make this therapy suitable in ALL. ${ }^{11}$ Due to its singlechain structure, blinatumomab is approximately one-third the size of the typical MoAb. The non-immunogenic linker protein that binds the anti-CD19 and anti-CD3 antibodies enables a great degree of rotational flexibility which allows for close proximity of malignant CD19-positive B-cells to CD3-positive T-cells, favoring direct lysis. The activity of blinatumomab and other BiTE ${ }^{\circledR}$ MoAbs does not depend on the specificity of the T-cell receptor and does not require major histocompatibility complex class 1 and/or peptide antigens, thereby allowing nonspecific recruitment of polyclonal T-cells and avoiding the downregulation of major histocompatibility complex class molecules, a known mechanism of tumor resistance. ${ }^{5}$

Blinatumomab engages the CD19-positive ALL blast cell to the CD3-positive T-cell, forming an immune synapsis that leads to upregulation of the T-cell activation markers CD25, CD69, CD2, interferon- $\gamma$, tumor necrosis factor- $\alpha$, interleukin (IL)-2, IL-6, and IL-10. These activated T-cells (especially the CD8-positive subset) induce perforin-mediated cytotoxicity via granzyme entry into the ALL blast, which subsequently leads to caspase activation and apoptosis of the blast cell. In addition to T-cell activation, blinatumomab causes marked T-cell proliferation. Furthermore, blinatumomab-activated T-cells are capable of serial killing of the CD19-positive target cells. One possible hypothesis for this serial lysis lies in the preferential binding of CD19 as compared to CD3 which potentially allows the $\mathrm{T}$-cells to be released from the target cells enabling them to bind to additional target B-cells. The T-cell proliferation and the serial killing of CD19-positive B-cells induced by blinatumomab explain why this MoAb is also effective in patients with a limited number of T-cells due to prior intensive therapy or early after hematopoietic stem cell transplantation (HSCT). ${ }^{12-16}$

\section{Pharmacokinetic data}

Several different blinatumomab administration schedules have been studied including short intravenous (IV) administration as well as 28-day continuous IV (CIV) administration.

The decision to give blinatumomab as a CIV infusion for 28 days was based on the evidence described in the first studies in which the majority of tumor responses were seen during the first 4 weeks of treatment. Subsequent studies of blinatumomab have therefore employed a CIV duration of 4 weeks with a 2-week break between cycles, and the main pharmacokinetic (PK) studies are derived according to this administration.

The mean ( \pm standard deviation) steady-state serum concentration of blinatumomab is $731 \pm 163 \mathrm{pg} / \mathrm{mL}$ and is reached within 1 day and is not modified in subsequent cycles. The volume of distribution is $1.61 \pm 0.74 \mathrm{~L} / \mathrm{m}^{2}$, with a mean clearance of $22.3 \pm 5 \mathrm{~L} / \mathrm{day} / \mathrm{m}^{2}$ and a half-life of $1.25 \pm 0.63$ hours. Systemic clearance is not affected by creatinine clearance, age, sex, weight, or body surface area.

The optimal dose of blinatumomab has been investigated in several studies. In vivo activity has been observed at doses as low as $5 \mu \mathrm{g} / \mathrm{m}^{2} /$ day, but several studies have shown that $\mathrm{CIV}$ doses of greater than or equal to $15 \mu \mathrm{g} / \mathrm{m}^{2} /$ day are needed for suppressing the ALL B-cells and that these doses lead to serum blinatumomab concentrations of $0.6 \mathrm{ng} / \mathrm{mL}$, which are maintained throughout the infusion period. ${ }^{12-17}$

Limited PK data are available in pediatric patients, but serum concentrations similar to those achieved in adults with attainment of steady-state concentrations within 48 hours were established in Phase I trials. ${ }^{18}$

\section{Pharmacodynamic data}

Data from the Phase II trial of blinatumomab in patients with MRD-positive ALL have shown that within the first few hours after the administration of blinatumomab, T-cell counts fall in all patients and recover to baseline levels in the subsequent days. ${ }^{12}$ A subsequent expansion of T-cells then occurs, and on average, their number more than doubles that of baseline within 2-3 weeks under continued infusion of blinatumomab. ${ }^{12}$ The initial fall in T-cells is attributed 
to a redistribution phenomenon thought to be caused by an increased adhesion of T-cells to the endothelium. Additionally, B-cells rapidly decrease and fall below the limit of detection in less than 2 days, remaining undetectable for the duration of the blinatumomab infusion. ${ }^{12,19,20}$ The low dose of blinatumomab needed for response (compared with conventional MoAb) is likely related to the high lytic potential of cytotoxic T-cells. These T-cells can rapidly adopt a serial lysis mode and can proliferate at the site of their activation. Activation of T-cells equally stimulates proliferation of CD4+ and CD8+ cytotoxic cells as long as target cells are available, but no signs of uncontrolled T-cell activation or T-cell anergy have been observed. ${ }^{12,19}$ Granzyme B is detectable in serum during the first 6-48 hours of blinatumomab treatment. A transient release of cytokines (especially IL-6, IL-10, and interferon- $\gamma$ ) is observed in most patients, the cytokine peak concentrations being dose dependent. ${ }^{12,19}$ Production of inflammatory cytokines can be problematic, and patients must be hospitalized for several days, particularly at the start of the first course (when the tumor burden is highest and a dose step at day 8 is used in the current schedules) to monitor possible infusion reactions or other toxicities (eg, neurological). No autoimmune responses have been reported to date in published trials.

Efforts have been made to find predictive markers of the efficacy of blinatumomab. In an analysis of 31 patients with $\mathrm{R} / \mathrm{R}$ ALL treated with blinatumomab at a single center, the T-regulatory $\left(\mathrm{T}_{\text {reg }}\right)$ lymphocytes of the T-cell compartment were monitored by flow cytometry, and a logistic regression model was developed to delineate responders vs nonresponders to blinatumomab. A high percentage of $\mathrm{T}_{\text {reg }}$ cells (over 12.5\%) and high serum lactate dehydrogenase level were found to be independent predictors of lack of response to blinatumomab. ${ }^{21}$ Upfront removal of $\mathrm{T}_{\text {reg }}$ cells might restore proliferation of T-cells, and thus may be a strategy to convert R/R ALL blinatumomab nonresponder patients to responders.

\section{Safety profile of blinatumomab}

The most significant toxicities noted in the studies performed in R/R ALL (Table 1) and in MRD-positive ALL using the CIV dose of $15 \mu \mathrm{g} / \mathrm{m}^{2} /$ day for 4 weeks with 2 weeks off between cycles were central nervous system (CNS) events and the cytokine release syndrome (CRS) (Table 2). ${ }^{22-27}$ The most common adverse CNS events included encephalopathy, aphasia, tremor, and disorientation, being reversible in most cases but leading to early discontinuation of the drug in others. While not entirely comprehended, the cause of blinatumomab-related CNS toxicity is thought to be the adherence of activated T-cells to the endothelium. The activated T-cells then cross the blood-brain barrier (BBB) and enter the CNS, where they bind to the CD19-positive B-cells, which could possibly cause cytokine release and disruption of the BBB. This T-cell-mediated inflammation of the CNS is also seen with CAR T-cells. ${ }^{3,4}$ To prevent neurological toxicity by blinatumomab, patients with the history or the presence of clinically relevant neurological pathology or active leukemia in CNS are excluded from treatment. Grade 3 neurological events are managed with temporary interruption of blinatumomab and dexamethasone treatment. If these events are resolved, blinatumomab can be reintroduced starting with the lowest dose $\left(5 \mu \mathrm{g} / \mathrm{m}^{2} /\right.$ day $)$. For seizures, appropriate anticonvulsant treatment must be given on blinatumomab preinitiation. On the development of grade 4 neurological events, permanent discontinuation of blinatumomab is mandatory. ${ }^{28}$

The CRS is thought to occur due to rapid lysis of tumor cells by T-lymphocytes during the first infusion. The release of pro-inflammatory cytokines is more pronounced during the beginning of the first cycle of treatment. In most patients, CRS symptoms are mild and flu-like, with fever and myalgia. In more severe cases, a severe inflammatory syndrome is associated with vascular leak, hypotension, pulmonary edema, coagulopathy, and multiorgan system failure. ${ }^{29}$ Baseline disease burden is associated with risk of CRS, and prephase dexamethasone $\left(10 \mathrm{mg} / \mathrm{m}^{2}\right.$ up to 5 days $)$ with or without cyclophosphamide (200 $\mathrm{mg} / \mathrm{m}^{2}$ up to 3 days) is required for patients with more than $50 \%$ blasts or a peripheral blast count over $15 \times 10^{9} / \mathrm{L}$. This pre-phase dexamethasone does not significantly impact the complete response (CR) rate. The reduction in the dose of blinatumomab to $5 \mu \mathrm{g} / \mathrm{m}^{2} /$ day (or $9 \mu \mathrm{g} /$ day) in the first week of the first cycle also prevents the development of CRS. ${ }^{28,29}$

Leukopenia with neutropenia, B-cell lymphocytopenia, and hypogammaglobulinemia can frequently be seen in patients treated with blinatumomab. Grade 3 neutropenia and febrile neutropenia were observed in $25 \%$ and $16 \%$ of patients included in the Phase II international trial in $R / R$ ALL, respectively. ${ }^{25}$ An increased risk of infection may occur, although it is difficult to determine whether this is related to the effects of the treatment with blinatumomab (immune dysfunction, B-cell lymphocytopenia, and neutropenia) or to the underlying active ALL. In the aforementioned trial, deaths due to sepsis or infection considered to possibly be related to blinatumomab occurred in three patients, none of whom was in remission. The B-cell lymphocytopenia 
Table I Development program of blinatumomab in adults and children with R/R acute lymphoblastic leukemia

\begin{tabular}{|c|c|c|c|}
\hline & $\begin{array}{l}\text { R/R Phase II GMALL } \\
\text { trial }\end{array}$ & $\begin{array}{l}\text { R/R Phase II international } \\
\text { confirmatory trial }\end{array}$ & $\begin{array}{l}\text { R/R pediatric Phase II } \\
\text { trial }\end{array}$ \\
\hline Patients enrolled & 36 & 189 & 39 \\
\hline \multirow[t]{3}{*}{ Dose of blinatumomab } & Varied by cohort & $\begin{array}{l}\text { First cycle: } 9 \mu \mathrm{g} / \mathrm{m}^{2} / \text { day in week I } \\
\text { and } 28 \mu \mathrm{g} / \mathrm{m}^{2} / \text { day thereafter }\end{array}$ & $\begin{array}{l}\text { First cycle: } 5 \mu \mathrm{g} / \mathrm{m}^{2} / \text { day } \\
\text { for } 7 \text { days, then } 15 \mu \mathrm{g} / \mathrm{m}^{2} / \text { day }\end{array}$ \\
\hline & $5 \mu \mathrm{g} / \mathrm{m}^{2} /$ day in week I and & Subsequent cycles: & Subsequent cycles: \\
\hline & $\begin{array}{l}15 \mu \mathrm{g} / \mathrm{m}^{2} / \text { day thereafter in } \\
\text { the extension phase }\end{array}$ & $28 \mu \mathrm{g} / \mathrm{m}^{2} /$ day $\times 4$ weeks & I5 $\mu \mathrm{g} / \mathrm{m}^{2} /$ day \\
\hline \multirow[t]{3}{*}{ Previous alloHSCT } & 15 (42\%) & 64 (34\%) & 25 (64\%) \\
\hline & & & Ist salvage: 6 \\
\hline & & & $\geq 2$ nd salvage: 19 \\
\hline No prior alloHSCT & 21 (58\%) & $125(66 \%)$ & 14 (36\%) \\
\hline Primary refractory & $3(8 \%)$ & $29(15 \%)$ & \\
\hline Ist salvage & II (31\%) & $55(29 \%)$ & \\
\hline$\geq 2$ nd salvage & $7(19 \%)$ & $4 \mathrm{I}(22 \%)$ & \\
\hline CR/CRh & $25(69 \%)$ & $8 \mathrm{I}(43 \%)$ & $12(3 \mid \%)^{*}$ \\
\hline RFS, median (months) & 7.6 & 5.9 & 5.6 \\
\hline OS, median (months) & 9.8 & 6.1 & 4.3 \\
\hline
\end{tabular}

Note: *Two additional patients had blast-free hypoplastic/aplastic bone marrow.

Abbreviations: R/R, relapsed/refractory; GMALL, German Multicenter Adult Acute Lymphoblastic Leukemia Group; alloHSCT, allogeneic hematopoietic stem cell transplantation; CR, complete response; CRh, CR with incomplete hematologic recovery; RFS, relapse-free survival; OS, overall survival.

and hypogammaglobulinemia are persistent during the blinatumomab therapy, and IV immunoglobulin replacement can be considered in patients with severely decreased serum immunoglobulin levels. Preliminary data from the first pediatric Phase I/II study suggest substantial similarities among the toxicity profiles described in adults. ${ }^{18}$

\section{Clinical studies in R/R ALL patients $\mathrm{R} / \mathrm{R} \mathrm{ALL}$ in adults}

Despite the improvements in the results of the therapy in most adult ALL patients, relapse is the most frequent cause of therapeutic failure, and occurs in a half of the patients, being more frequent with increasing age. Advanced genomic techniques investigated the clonal diversity and evolution in acute leukemia. Studies of pediatric ALL demonstrated that in individual patients, there are multiple genetic subclones of leukemia-initiating cells, with a complex clonal architecture. ${ }^{30}$ Separate studies also investigating pediatric ALL determined that the clonal basis of relapse was variable and complex, with relapse often evolving from a clone ancestral to the predominant de novo leukemia clone. ${ }^{31}$ The results of the conventional rescue chemotherapy are poor, and only a small fraction of patients can achieve prolonged remission after alloHSCT. New therapeutic options are clearly required to try to solve this unmet medical need.

Table 2 Main toxicities observed in clinical trials in R/R acute lymphoblastic leukemia

\begin{tabular}{|c|c|c|c|c|}
\hline Trial (reference) & Blinatumomab schedule & $\begin{array}{l}\text { Most common } \\
\text { adverse events }\end{array}$ & $\begin{array}{l}\text { Most common grade 3-4 } \\
\text { adverse events }\end{array}$ & $\begin{array}{l}\text { Fatal adverse } \\
\text { events }\end{array}$ \\
\hline $\begin{array}{l}\text { R/R Phase II GMALL trial } \\
(\mathrm{n}=36)^{22}\end{array}$ & $\begin{array}{l}\text { Varied by cohort } \\
5 \mu \mathrm{g} / \mathrm{m}^{2} / \text { day in week I and } \\
15 \mu \mathrm{g} / \mathrm{m}^{2} / \text { day thereafter in the } \\
\text { extension phase }\end{array}$ & $\begin{array}{l}\text { Pyrexia, fatigue, } \\
\text { headache, tremor, } \\
\text { leukopenia }\end{array}$ & $\begin{array}{l}\text { Transient leukopenia } \\
\text { and thrombocytopenia }\end{array}$ & 6 \\
\hline $\begin{array}{l}R / R \text { Phase II international } \\
\text { confirmatory trial }(n=189)^{25}\end{array}$ & $\begin{array}{l}\text { First cycle: } 9 \mu \mathrm{g} / \mathrm{m}^{2} / \text { day in } \\
\text { week I and } 28 \mu \mathrm{g} / \mathrm{m}^{2} / \text { day } \\
\text { thereafter } \\
\text { Subsequent cycles: } \\
28 \mu \mathrm{g} / \mathrm{m}^{2} / \text { day } \times 4 \text { weeks }\end{array}$ & $\begin{array}{l}\text { Pyrexia, headache, } \\
\text { febrile neutropenia }\end{array}$ & $\begin{array}{l}\text { Febrile neutropenia, } \\
\text { neutropenia, anemia }\end{array}$ & 28 \\
\hline $\begin{array}{l}R / R \text { pediatric Phase II trial } \\
(n=39)^{27}\end{array}$ & $\begin{array}{l}\text { First cycle: } 5 \mu \mathrm{g} / \mathrm{m}^{2} / \text { day } \\
\text { for } 7 \text { days, then } 15 \mu \mathrm{g} / \mathrm{m}^{2} / \text { day } \\
\text { Subsequent cycles: } \\
15 \mu \mathrm{g} / \mathrm{m}^{2} / \text { day }\end{array}$ & $\begin{array}{l}\text { Pyrexia, anemia, } \\
\text { nausea, headache } \\
\text { Increased AST and ALT }\end{array}$ & $\begin{array}{l}\text { Anemia, pyrexia, increased AST } \\
\text { and ALT, febrile neutropenia }\end{array}$ & 0 \\
\hline
\end{tabular}

Abbreviations: R/R, relapsed/refractory; GMALL, German Multicenter Adult Acute Lymphoblastic Leukemia Group; AST, aspartate aminotransferase; ALT, alanine aminotransferase. 
The first trial of blinatumomab in adults with $\mathrm{R} / \mathrm{R}$ ALL was an open-label, multicenter, exploratory Phase II study performed by the German Multicenter Adult Acute Lymphoblastic Leukemia Group. ${ }^{24}$ R/R ALL was defined as ALL with $>5 \%$ blasts in bone marrow (BM), and Philadelphia chromosome $(\mathrm{Ph})$-positive ALL if ineligible for tyrosine kinase inhibitors treatment, $>3$ months after alloHSCT or $>6$ months after autologous HSCT. The study included a dose-finding phase with three cohorts of patients followed by an extension phase with the schedule with the best safety profile. The primary endpoints were $\mathrm{CR}$ and $\mathrm{CRh}$ (CR with incomplete hematologic recovery, defined as $\leq 5 \%$ blasts in the BM, no evidence of circulating blasts or extramedullary disease, and partial recovery of peripheral blood counts [at least platelets $>50,000 / \mu \mathrm{L}$, hemoglobin $>7 \mathrm{~g} / \mathrm{dL}$, and absolute neutrophil count $>500 / \mu \mathrm{L}]$ ) within two cycles of treatment. Two cycles of blinatumomab were scheduled, followed by three additional consolidation cycles or alloHSCT in $\mathrm{CR} / \mathrm{CRh}$ patients. Thirty-six patients were included (three primary refractory, 16 after first relapse and two after $\geq 2$ relapses, 15 in relapse after HSCT, two Ph-positive ALL, and four $\mathrm{t}(4 ; 11)$-positive ALL). The best safety profile was observed in the cohort including $5 \mu \mathrm{g} / \mathrm{m}^{2} /$ day in week 1 and $15 \mu \mathrm{g} / \mathrm{m}^{2} /$ day thereafter and was selected for the extension phase. $\mathrm{CR} / \mathrm{CRh}$ was attained in $25 / 36$ patients (69\%), with a CR rate of $42 \%(15 / 36)$ attained after the first cycle of blinatumomab in 18 out of 25 patients. MRD negativity $\left(<10^{-4}\right)$ across all cycles was achieved in $88 \%$ of responders (22/25). In the last update, at a median follow-up of 28.9 months, the median of relapse-free survival (RFS) was 8.8 months, and the median overall survival (OS) was 9.8 months (14.9 months after censoring of HSCT). Regarding safety, CRS requiring treatment discontinuation or interruption of blinatumomab occurred in three patients, neurological events requiring interruption of the treatment were observed in six patients (all restarted blinatumomab at a dose of $5 \mu \mathrm{g} / \mathrm{m}^{2}$, although two patients had recurring events and permanently stopped therapy), and one patient developed a fatal fungal encephalitis.

The results of a global Phase II study in R/R adult ALL patients with the following inclusion criteria have recently been published: ${ }^{25} \mathrm{Ph}$-negative ALL with primary resistance to frontline therapy, early relapse (duration of first $\mathrm{CR}<12$ months), and second or later relapses. More than $10 \%$ blasts in BM were required to include the patients in the trial. Treatment consisted of an induction phase including one to two cycles of blinatumomab $\left(9 \mu \mathrm{g} / \mathrm{m}^{2} /\right.$ day in week 1 and $28 \mu \mathrm{g} / \mathrm{m}^{2} /$ day thereafter, as established in the previous
Phase II dose-finding study) followed by a consolidation period with one to three cycles of blinatumomab. The primary endpoint was $\mathrm{CR} / \mathrm{CRh}$ within the first two cycles. Out of the 189 patients treated, 81 (43\%) achieved CR/CRh within the first two cycles (CR, 33\% [63/189]; CRh, 10\% [18/189]), with $79 \%(64 / 81)$ of the responders achieving $\mathrm{CR} / \mathrm{CRh}$ in cycle 1 . The $\mathrm{CR} / \mathrm{CRh}$ rates were similar in the ALL subgroups, including elderly patients (11/25; 44\%) and patients with prior alloHSCT $(29 / 64 ; 45 \%)$. AlloHSCT was performed in $32(40 \%)$ out of the 81 patients with CR/CRh. At a median follow-up of 8.9 months, the median RFS was 5.9 months. The median OS was 6.1 months (median follow-up 9.8 months), without differences after censoring the follow-up at alloHSCT. The OS was significantly better for patients achieving $\mathrm{CR} / \mathrm{CRh}$ after two treatment cycles (median of 9.9 months vs 2.7 months). Sixty out of 73 patients (82\%) who achieved CR/CRh within the first two cycles achieved MRD negativity (59 in cycle 1 ). The most frequent non-neurologic grade $\geq 3$ adverse events (AEs) found in $>5 \%$ of patients were febrile neutropenia (25\%), neutropenia (16\%), anemia (14\%), thrombocytopenia $(8 \%)$, and infections (pneumonia in $9 \%$, sepsis in $6 \%$ ). Three patients $(2 \%$ ) had grade $3 \mathrm{CRS}$ (no grade 4 or $5 \mathrm{CRS}$ events were registered). Grade $\geq 3$ neurologic events were observed in $24(13 \%)$ patients (grade 4 in four patients, with no cases of grade 5), and occurred in cycle 1 in $87 \%$ of cases. Grade 5 AE occurred in 28 (15\%) patients, none of whom were in documented $\mathrm{CR}$, and deaths were considered unrelated to blinatumomab.

A Phase II single-arm, multicenter trial aimed to evaluate the efficacy of blinatumomab in adults with $\mathrm{R} / \mathrm{R}$ Ph-positive ALL (clinicaltrials.gov NCT02000427) is currently being conducted, and the accrual of the 41 patients has been completed. Adults ( $\geq 18$ years) with $\mathrm{R} / \mathrm{R}$ Ph-positive ALL who were resistant or intolerant to at least one second-generation tyrosine kinase inhibitor (dasatinib, nilotinib, bosutinib, ponatinib) were eligible. An induction phase with two cycles of blinatumomab followed by up to three consolidation cycles for subjects who achieved $\mathrm{CR} / \mathrm{CRh}$ within two induction cycles was scheduled. The primary endpoint was the $\mathrm{CR} / \mathrm{CRh}$ rate within two cycles of treatment.

An international Phase III, randomized, multicenter, openlabel study aimed to investigate the efficacy of blinatumomab vs standard of care (SOC) chemotherapy in adults with $\mathrm{R} / \mathrm{R}$ Ph-negative BCP ALL (clinicaltrials.gov NCT02013167) is now underway. Adult patients ( $\geq 18$ years) in untreated first relapse with a first remission duration $<12$ months or in untreated second or greater relapse or relapsed at any 
time after alloHSCT are eligible. A 2:1 randomization of blinatumomab vs SOC chemotherapy is planned. The blinatumomab arm includes two induction cycles followed by up to three consolidation cycles and by blinatumomab maintenance. AlloHSCT is allowed to be performed at any time in patients in CR/CRh after two cycles of blinatumomab or after SOC chemotherapy. No cross-over between arms is allowed. The primary endpoint is OS. Four hundred patients are expected to be recruited.

\section{R/R ALL in children}

The first results of a Phase I/II study of blinatumomab in pediatric patients with R/R BCP ALL were presented in the 2014 Meeting of the American Society of Hematology (ASH). ${ }^{18}$ A total of 70 patients (Phase I/II and Phase II studies) were included. Eligible patients were less than 18 years old with BCP ALL in second or later BM relapse, in any BM relapse after alloHSCT, or refractory to induction or reinduction therapy. Escalating dose levels of $5 \mu \mathrm{g} / \mathrm{m}^{2} /$ day, $15 \mu \mathrm{g} / \mathrm{m}^{2} /$ day, and $30 \mu \mathrm{g} / \mathrm{m}^{2} /$ day and stepwise dosing of $5-15 \mu \mathrm{g} / \mathrm{m}^{2} /$ day or $15-30 \mu \mathrm{g} / \mathrm{m}^{2} /$ day were evaluated. The primary endpoint of the Phase I part of the study was to determine the maximum tolerated dose (MTD). Forty-one patients received a total of 73 cycles (median 1 cycle). Eight (20\%) patients had refractory disease, and seven (17\%) had experienced at least two BM relapses. Twenty-six (63\%) patients had relapsed following HSCT. The MTD was established at $15 \mu \mathrm{g} / \mathrm{m}^{2} /$ day. To decrease the risk of CRS, a stepwise dose of $5-15 \mu \mathrm{g} / \mathrm{m}^{2} /$ day was recommended for the Phase II part of the study $\left(5 \mu \mathrm{g} / \mathrm{m}^{2} /\right.$ day for 7 days, then $15 \mu \mathrm{g} / \mathrm{m}^{2} /$ day in the first cycle and $15 \mu \mathrm{g} / \mathrm{m}^{2} /$ day in subsequent cycles). Across all dosing levels, 13 (32\%) patients had CR, with ten (77\%) achieving MRD negativity. Of these 13 patients, nine (69\%) underwent alloHSCT. The median RFS was 8.3 months, and the median OS was 5.7 months with a median follow-up of 12.4 months.

The primary endpoint for the Phase II part of the study was the $\mathrm{CR} / \mathrm{CRh}$ rate. The results from the first 39 patients recruited were presented separately in the same ASH Meeting. ${ }^{27}$ Sixteen (41\%) patients had one, and $16(41 \%)$ had two or more prior salvage therapies; seven $(18 \%)$ were either primary refractory or had refractory relapse. Twenty-five (64\%) patients had received prior alloHSCT. Out of the 39 patients, 34 (87\%) had relapsed within 6 months prior to study entry. During the first two treatment cycles, 12 patients (31\%) achieved CR, mainly during the first cycle. Two additional patients (5\%) had blast-free hypoplastic or aplastic BM. Among the patients with $\mathrm{CR}$ in the first two cycles, five $(42 \%)$ had complete MRD response. The median RFS was 5.6 months, and the median OS was 4.3 months at 6 months of follow-up. Six (50\%) out of the 12 patients with CR proceeded to alloHSCT.

\section{Causes of failure of treatment with blinatumomab}

Despite the promising results of treatment with blinatumomab, a significant number of patients do not respond or experience relapse. The causes of this resistance are not well known. In a significant proportion of patients, the leukemic blasts do not express CD19 on their surface, suggesting CD19 internalization or, most probably, selection of CD19-negative subclones being present at low level at relapse. On the other hand, a high percentage of $\mathrm{T}_{\text {reg }}$ cells (that regulate the $\mathrm{T}$-cell proliferation) and high serum lactate dehydrogenase levels (probably reflecting the leukemic burden) were independent predictors of lack of response to blinatumomab. ${ }^{21}$ Some of the relapses after blinatumomab are extramedullary, especially in CNS, suggesting an insufficient activity of blinatumomab in sanctuary sites.

\section{Current and future development of blinatumomab for ALL}

From the results of the Phase II trials of blinatumomab in R/R ALL, blinatumomab (Blincyto ${ }^{\circledR}$ ) was approved by the US Food and Drug Administration on December 3, 2014 following an accelerated review process, for patients with R/R Ph-negative ALL. Blinatumomab will be submitted to the European Medicines Agency during 2015.

The results of the ongoing Phase II trial in $\mathrm{R} / \mathrm{R}$ patients with Ph-positive ALL are awaited with interest. The preliminary results of a global Phase II trial of blinatumomab in patients with MRD-positive BCP ALL have recently been reported, ${ }^{28}$ showing reversion to an MRD-negative status in $80 \%$ of patients after two cycles of blinatumomab. In addition, two Phase III studies, one designed by the National Cancer Institute/Children's Oncology Group and another by the International Berlin-Frankfurt-Münster, are under development for pediatric patients. On the other hand, an ongoing Phase III study of combination chemotherapy with or without blinatumomab in patients with newly diagnosed Ph-negative B-lineage ALL is being conducted in the US by the Eastern Cooperative Oncology Group. In summary, blinatumomab has shown promising efficacy with a favorable safety profile in patients with 
$\mathrm{R} / \mathrm{R}$ or MRD-positive BCP ALL and is currently being investigated in earlier phases of the disease, confirming the importance of immunotherapy as a therapeutic strategy for patients with ALL. ${ }^{32}$

\section{Acknowledgments}

This study was supported in part by grants from the Red Temática de Investigación Cooperativa en Cáncer (RTICC, FEDER) (RD12/0036/0029), 2014 SGR225 (GRE) Generalitat de Catalunya, and PI14/01971 from Fondo de Investigaciones Sanitarias, Instituto de Salud Carlos III, and Obra Social "La Caixa", Spain.

\section{Disclosure}

The authors report no conflicts of interest in this work.

\section{References}

1. Nelson MH, Paulos CM. Novel immunotherapies for hematologic malignancies. Immunol Rev. 2015;263(1):90-105.

2. Weiland J, Elder A, Forster V, Heidenreich O, Koschmieder S, Vormoor J. CD19: a multifunctional immunological target molecule and its implications for B lineage acute lymphoblastic leukemia. Pediatr Blood Cancer. 2015;62(7):1144-1148.

3. Maude SL, Frey N, Shaw PA, et al. Chimeric antigen receptor T cells for sustained remissions in leukemia. $N$ Engl J Med. 2014;371(16): 1507-1517.

4. Lee DW, Kochenderfer JN, Stetler-Stevenson M, et al. T cells expressing CD19 chimeric antigen receptors for acute lymphoblastic leukaemia in children and young adults: a phase 1 dose-escalation trial. Lancet. 2015;385(9967):517-528.

5. Zimmerman Z, Maniar T, Nagorsen D. Unleashing the clinical power of T cells: CD19/CD3 bi-specific T cell engager (BiTE $\left.{ }^{\circledR}\right)$ antibody construct blinatumomab as a potential therapy. Int Immunol. 2015;27(1): 31-37.

6. Thomas X. Blinatumomab: a new era of treatment for adult ALL? Lancet Oncol. 2015;16(1):6-7.

7. Bassan R. Toward victory in adult ALL: blinatumomab joins in. Blood. 2012;120(26):5094-5095.

8. Nagorsen D, Baeuerle PA. Immunomodulatory therapy of cancer with T cell-engaging BiTE antibody blinatumomab. Exp Cell Res. 2011;317(9): 1255-1260.

9. Bargou R, Leo E, Zugmaier G, et al. Tumor regression in cancer patients by very low doses of a T cell-engaging antibody. Science. 2008; 321(5891):974-977.

10. Hoffmann P, Hofmeister R, Brischwein K, et al. Serial killing of tumor cells by cytotoxic T cells redirected with a CD19-/CD3bispecific single-chain antibody construct. Int J Cancer. 2005;115(1): 98-104.

11. Raponi S, De Propris MS, Intoppa S, et al. Flow cytometric study of potential target antigens (CD19, CD20, CD22, CD33) for antibodybased immunotherapy in acute lymphoblastic leukemia: analysis of 552 cases. Leuk Lymphoma. 2011;52(6):1098-1107.

12. Klinger $M$, Brandl $C$, Zugmaier $G$, et al. Immunopharmacologic response of patients with B-lineage acute lymphoblastic leukemia to continuous infusion of T cell-engaging CD19/CD3-bispecific BiTE antibody blinatumomab. Blood. 2012;119(26):6226-6233.

13. Baeuerle PA, Reinhardt C. Bispecific T-cell engaging antibodies for cancer therapy. Cancer Res. 2009;69(12):4941-4944.
14. Portell CA, Wenzell CM, Advani AS. Clinical and pharmacologic aspects of blinatumomab in the treatment of B-cell acute lymphoblastic leukemia. Clin Pharmacol. 2013;5(suppl 1):5-11.

15. Rathi C, Meibohm B. Clinical pharmacology of bispecific antibody constructs. J Clin Pharmacol. 2015;55(suppl 3):S21-S28.

16. Ruella M, Gill S. How to train your T cell: genetically engineered chimeric antigen receptor $\mathrm{T}$ cells versus bispecific $\mathrm{T}$-cell engagers to target CD19 in B acute lymphoblastic leukemia. Expert Opin Biol Ther. 2015;15(6):761-766.

17. Wu B, Hijazi Y, Wolf A, et al. Pharmacokinetics (PK) of blinatumomab and its clinical implications. J Clin Oncol. 2013;31:sul;abstr3048.

18. von Stackelberg A, Locatelli F, Zugmaier G, et al. Phase 1/2 study in pediatric patients with relapsed/refractory B-cell precursor acute lymphoblastic leukemia (BCP-ALL) receiving blinatumomab treatment. Blood. 2014; 124:abstr2292.

19. Schub A, Nägele V, Zugmaier G, et al. Immunopharmacodynamic response to blinatumomab in patients with relapsed/refractory B-precursor acute lymphoblastic leukemia (ALL). J Clin Oncol. 2013; 31:sul;abstr7020.

20. Zugmaier G, Topp MS, Alekar S, et al. Long-term follow-up of serum immunoglobulin levels in blinatumomab-treated patients with minimal residual disease-positive B-precursor acute lymphoblastic leukemia. Blood Cancer J. 2014;4:244.

21. Duell J, Dittrich M, Bedke T, et al. Crucial role of regulatory T cells in predicting the outcome of the $\mathrm{T}$ cell engaging antibody blinatumomab in relapsed and refractory B precursor ALL patients. Blood. 2014;124: abstr2291.

22. Topp MS, Kufer P, Gökbuget N, et al. Targeted therapy with the T-cellengaging antibody blinatumomab of chemotherapy-refractory minimal residual disease in B-lineage acute lymphoblastic leukemia patients results in high response rate and prolonged leukemia-free survival. J Clin Oncol. 2011;29(18):2493-2498.

23. Topp MS, Gökbuget N, Zugmaier G, et al. Long-term follow-up of hematologic relapse-free survival in a phase 2 study of blinatumomab in patients with MRD in B-lineage ALL. Blood. 2012;120(26):5185-5187.

24. Topp MS, Gökbuget N, Zugmaier G, et al. Phase II trial of the anti-CD19 bispecific T cell-engager blinatumomab shows hematologic and molecular remissions in patients with relapsed or refractory B-precursor acute lymphoblastic leukemia. J Clin Oncol. 2014;32(36):4134-4140.

25. Topp MS, Gökbuget N, Stein AS, et al. Safety and activity of blinatumomab for adult patients with relapsed or refractory B-precursor acute lymphoblastic leukaemia: a multicentre, single-arm, phase 2 study. Lancet Oncol. 2015;16(1):57-66.

26. Goekbuget N, Dombret H, Bonifacio M, et al. BLAST: a confirmatory, single-arm, phase 2 study of blinatumomab, a bispecific T-cell engager $\left(\mathrm{BiTE}^{\circledR}\right)$ antibody construct, in patients with minimal residual disease B-precursor acute lymphoblastic leukemia (ALL). Blood. 2014;124:abstr379.

27. Gore L, Locatelli F, Zugmaier G, et al. Initial results from a phase 2 study of blinatumomab in pediatric patients with relapsed/refractory B-cell precursor acute lymphoblastic leukemia. Blood. 2014;124: abstr3703.

28. Barrett DM, Teachey DT, Grupp SA. Toxicity management for patients receiving novel T-cell engaging therapies. Curr Opin Pediatr. 2014 26(1):43-49.

29. Teachey DT, Rheingold SR, Maude SL, et al. Cytokine release syndrome after blinatumomab treatment related to abnormal macrophage activation and ameliorated with cytokine-directed therapy. Blood. 2013; 121(26):5154-5157.

30. Jan M, Majeti R. Clonal evolution of acute leukemia genomes. Oncogene. 2013;32(2):135-140.

31. Ma X, Edmonson M, Yergeau D, et al. Rise and fall of subclones from diagnosis to relapse in pediatric B-acute lymphoblastic leukaemia. Nat Commun. 2015;6:6604.

32. Ai J, Advani A. Current status of antibody therapy in ALL. Br J Haematol. 2015;168(4):471-480. 


\section{Publish your work in this journal}

OncoTargets and Therapy is an international, peer-reviewed, open access journal focusing on the pathological basis of all cancers, potential targets for therapy and treatment protocols employed to improve the management of cancer patients. The journal also focuses on the impact of management programs and new therapeutic agents and protocols on

patient perspectives such as quality of life, adherence and satisfaction. The manuscript management system is completely online and includes a very quick and fair peer-review system, which is all easy to use. Visit http://www.dovepress.com/testimonials.php to read real quotes from published authors.

Submit your manuscript here: http://www.dovepress.com/oncotargets-and-therapy-journal 